\title{
Shared Societies and Economic Development
}

\author{
CASSAM UTEEM
}

\begin{abstract}
One of the main global challenges in the world today is the management of diversity and the creation of socially cohesive societies. The Club de Madrid, through its Shared Societies Project, while underscoring the political and ethical aspects of social inclusion aims at providing current leadership with tested solutions to meet that challenge. Mutual respect, equality of opportunity, absence of discrimination and democracy are some of the basic principles that govern such societies. There is obviously an economic argument for social inclusion which is all too often overlooked although evidence exists that social inclusion pays off in higher economic growth.
\end{abstract}

KEYWORDS Club de Madrid; diversity; shared society; social inclusion; democracy; economic argument

The Club de Madrid (CdM) is the largest global network of democratic former Heads of State and Government, dedicated to strengthening democratic values and leadership around the world by drawing on the experience and resources of its Members. From our personal experience in and out of office we all share the conviction that within a world that is increasingly diverse and where economic, social and political inequalities continue to prevail, the question of how we live together and manage our differences is extremely important and represents one of the most important challenges of our time.

The vast majority of countries in the world today have a minority population of at least 10 percent. The reasons for this diversity vary. Sometimes it is the result of migration but very often it is a consequence of the colonial era. In the CdM, we recognize that the particular features of each situation may differ, but we also believe that it should be our goal to find ways of ensuring that different communities within a given country live in harmony with each other by working towards the creation of a socially cohesive society.

A socially cohesive society is a stable, safe and just society, one that is based on the promotion and protection of human rights, non-discrimination and tolerance; a society that respects diversity, equality of opportunity, solidarity, security and participation of all people including disadvantaged and vulnerable groups and individuals. The members of such a society feel at home and are able to provide their full contribution to the community.

A society where these conditions exist, or at least where they are being actively sought, is one that we define as a 'shared society'. The CdM has established the Shared Societies Project as its contribution to the challenge of achieving such an ambitious goal. 
We, as Members of CdM, want to provide current leaders and the wider society with greater understanding of the benefits of social inclusion and the incentives and means to act in order to achieve it.

Our first task is to champion the importance of building shared societies and making the case for it - politically, ethically and economically. We believe it is a vital conversation of our times.

We have identified the following four basic principles that underlie a shared society:

- The first - and one that is at the centre of our approach - is the need for mutual respect, meaning the respect for the dignity of each of us even though we may speak different languages, have different cultures, follow different religions and may look different. Respect itself is built on the knowledge and understanding of the other. It is therefore imperative that we provide for opportunities to meet and know the other in order to build such respect. In turn, respect makes us aware of the needs of others and the circumstances in which their rights may be overlooked or ignored.

- The second and third key elements are quality of opportunity and absence of discrimination. If we are all given the same treatment, if we are equal before the law, if our rights are guaranteed, we feel more secure and we are less likely to feel threatened by the State or by other sections of the community.

- And fourth, we believe that democracy and democratic participation provide the best kind of structures for ensuring that all sections of the community are able to speak for themselves and express their needs, their choices and their preferences.

Those four principles are the reference points that we believe should ground our work on social cohesion.

The focus of our efforts is political leadership and the question of political will. Political leaders are critical in determining if a society is inclusive and shared or if it excludes and marginalizes people and denies them equal opportunity. Political leadership is important for reassuring people and challenging those who exploit the fears of communities; it is encourage an inclusive approach; it is essential to make the cogent argument that our society is a better place for all of us if we embrace diversity, even if this might be initially challenging.

Of course, political leaders cannot achieve all this on their own. All sections of society have a part to play. There are many examples of civil society groups working to improve community relations and bringing marginalized sections of the population into the mainstream - but their efforts will remain limited if the political leadership is inadequate. In many places such leadership is not sufficiently present and we need to review the reasons why this is the case and how it can be changed. We need to look at how international bodies can work with and support leaders in recognizing the importance of this approach. We want to show that it is possible to promote shared societies everywhere, even in places where leaders would argue there is nothing else they can do.

Not only ethically, but also politically, social inclusion makes sense. The 7 worst-ranked countries in the Index of Failed States are among the 14 that have the highest rate of group grievances.

Furthermore, there is an economic argument for social inclusion - one that seems obvious but is often overlooked. If sections of society are marginalized they will contribute less to the economy. They will have poorer education and, hence limited skills to contribute. They have less capital to invest. Recent studies by World Bank economists (Foa and Jorgensen, 2008) suggest that the countries in the top quintile of 'inclusive' societies have seen their GDP rise over the past 10 years 18.6 percent more than those countries in the bottom quintile. This offers evidence that social inclusion pays off in higher economic growth.

Excluded groups may also be less willing to contribute to a society that they feel neither respect them nor treat them as full citizens. They may go further and resist the status quo and this may cost the State a good deal of its surplus wealth to maintain stability as it may resort to increased security measures, such as enlarged security forces, enhanced equipment for the security services, and larger and stronger prisons. External capital - Foreign Direct Investment - is unlikely to 


\section{Uteem: Shared Societies and Economic Development}

invest in a society if it seems unstable and where tension is high.

Women all over the world have suffered from economic discrimination. Only recently we are seeing how the participation of women as 'economic-citizens' is contributing to economic growth in their countries and regions. The data on the high repayment rate of micro loans credited to women, for example, is astonishing in this regard.

We need to challenge the assumption that marginalized and vulnerable groups are a drain on the economy, particularly in a world that has risked financial meltdown, that is confronted with continued high unemployment rates and where people feel increasingly insecure. In recent years, the CdM has been working with the regional government of Madrid, which has been making the point forcefully that the contribution that immigrants are making to the local economy in Madrid is much greater than the amount of money they are sending back home, and equally, the size of their contribution to the local economy is much larger than the cost of social services from which they benefit.

It is important to equip ourselves with these types of information and analysis to refute the negative arguments, where they exist. But this will not be enough. Nationalistic populism can easily build on the uncertainty that many citizens feel about foreigners or immigrants - those different from themselves, particularly the poor and disadvantaged, as we have seen far too clearly in the recent European Parliamentary elections. It may then become difficult for rational arguments to be heard.

In the CdM, we have been working to make the case that diverse societies that are cohesive and inclusive make economic sense: obviously, cooperation is better than conflict. It is therefore cost effective and beneficial in every way to invest in the building of shared societies. A couple of years back, the Club de Madrid (2011) convened a Reference Group of Experts that produced a report (17) on the economic rationale for shared societies. Building on these findings, the Members of the Club have adopted a Statement and a set of policy recommendations (Club de Madrid, 2011: 11) that have been offered to current political and economic leaders, at both national and international level, as a potentially more effective and fairer framework to economic policy and inter-group relations.

Allow me here to share with you some extracts from the Statement:

We urge all leaders and global financial institutions to recognize that Shared Societies benefit everyone and to take all steps to make them a reality worldwide. Any other policy is short sighted. We also call on them to adopt the Call to Action ... of the Club de Madrid as a means of effectively achieving a truly Shared Society in their own countries.

Our Expert Working Group has identified Ten Guiding Principles that should guide national and international policymakers in their discussions and formulations of to fiscal, social, and economic development policy.

We call on current leaders and international institutions to adopt these Ten Guiding Principles as a framework for their own policies and programmes and as a means to a fairer and more inclusive international order that will ensure a global environment in which individual countries are encouraged to build their own Shared Society. (Club de Madrid, 2011: 12-13)

The CdM has relatively easier access to political leaders and therefore focuses on the role of political leadership. However, political leaders cannot replace the contribution of individuals in their own communities and the work of international and civic organizations. However, they can often offer an enabling leadership that encourages or makes it possible for attitudes to change and communities to act. This is also relevant for those in leadership positions within civil society.

Social inclusion is about all of us. It is about each one of us individually, as citizens, as defenders of Human Rights. It is not about 'fitting the others in', but about building common ground where all of us feel safe to develop our potential and contribute on the basis of our differences. 


\section{Development 57(1): Upfront}

\section{References}

Club de Madrid (2011) The Economics of Shared Societies. Madrid: Club de Madrid, http://www.clubmadrid.org/img/ secciones/Policy_Perspectives_on_the_Economics_of_Shared_Societies.pdf, accessed 2 September 2014 and http:// www.clubmadrid.org/img/secciones/The_Economics_of_Shared_Societies_Publication.pdf, accessed 2 September 2014.

Foa, Roberto and Steen Lau Jorgensen (2008) 'Defusing Collective Violence: The Economic Arguments', in Clem McCartney (ed.) The Shared Societies Project Background Papers: Responding to Social Cohesion Challenges. Madrid: Club de Madrid. 